ORIGINAL ARTICLE

\title{
Efficacy of Preoperative Misoprostal in Reducing Hemorrhage during Abdominal Myomectomy
}

\author{
IRUM BATOOL HASHMI ${ }^{1}$, ASIM SHAFI ${ }^{2}$, AYESHA CHOUDHARY ${ }^{3}$, WASIM AHMAD ${ }^{4}$, MUHAMMAD HAMAYUN KHAN ${ }^{5}$, \\ MONIZA IMRAN 6 \\ ${ }^{1}$ Assistant Professor, Obs / Gynae Gomal Medical College, Dera Ismail Khan \\ ${ }^{2}$ Associate Professor of Surgery, Bakhtawar Amin Medical \& Dental College Multan \\ ${ }^{3}$ Assistant Professor General Surgery, Services Hospital Lahore \\ ${ }^{4}$ Assistant Professor General Surgery, Gomal Medical College, Dera Ismail Khan \\ ${ }^{5}$ Assistant Professor of Surgery DHQ/MMMT hospitals/ Gomal Medical College, Dera Ismail Khan \\ ${ }^{6}$ Consultant Gynaecologist, PAF Hospital, Mianwali \\ Correspondence to: Dr Irum Batool Hashmi, Email: batool_irum@yahoo.com, Contact: +923005796291
}

\begin{abstract}
Objective: The aim of this study is to determine the efficacy of preoperative misoprostal in reducing hemorrhage during abdominal myomectomy.

Study Design: Prospective comparative randomized double blinded

Place and Duration: Conducted at DHQ Zanana hospital Dera Ismail Khan for one year duration from January 2019 to December 2019.

Methods: Total 100 patients underwent abdominal myomectomy were presented in this study. Patients were aged between 18-45 years of age. Patients' detailed demographics including age, body mass index and parity were recorded after taking informed written consent. Patients were categorized equally into two groups, I and II. Group I had 50 patients and received single dose 400 micrograms of misoprostol transrectally one hour preoperatively and group II had 50 patients and received 2-tablets of placebo preoperatively. Outcomes intraoperative blood loss, blood transfusion, hysterectomy and complications among both groups were assessed. Complete data was analyzed by SPSS 23.0 version.

Results: Mean age of the patients was $32.16 \pm 9.44$ with mean BMl $26.07 \pm 10.44 \mathrm{~kg} / \mathrm{m}^{2}$. There were no significantly difference among age and body mass among both groups. 60 Patients had 0 parity, 30 patients had parity 1 and the rest were had parity 2 . Mean pre-operative hemoglobin in group I was $13.64 \pm 8.55$ and postoperative was $9.88 \pm 8.55$ and in group II mean pre-operative hemoglobin was $13.55 \pm 8.55$ and post-operative was 9.12 \pm 5.55 . Mean intraoperative blood loss in group I was $388.17 \pm 37.18 \mathrm{ml}$ and in group II was $501.16 \pm 17.64 \mathrm{ml}$. Post-operatively blood transfusion in group I was among $2(4 \%)$ cases and $3(6 \%)$ in group II. Mean hospital stay in group II was greater as compared to group I. Nausea, vomiting and shivering were the complications found in this study.

Conclusion: We concluded in this study that the use ofmisoprostol preoperatively during abdominal myomectomy was effective safe and useful in reduction of intraoperative blood loss and post-operatively blood transfusion among patients.
\end{abstract}

Keywords: Abdominal myomectomy, Misoprostol, Placebo, Intraoperative, Blood loss

\section{INTRODUCTION}

Uterotones such as oxytocin, ergometrin, and misoprostol are usually supplied routinely after the fetus is given to women in obstetric surgery[1] and may not diminish intraoperating blood loss (part of PPH). This intraoperative bleeding might cause maternal morbidity and mortality significantly[2]. Moreover, it will be essential for the patient to survive in a condition of heavy bleeding soon after birth the period between uterotonic injection and starting of action[2]. A key contribution to blood-thinning[3],[4],[5] is placental anomalies. Placental abruption, placental previa, placenta attached placenta (accrete, increta and percreta), and placenta retained are typical anomalies that can be found in pregnancy. For example, $36 \%$ of pregnancyrelated deaths owing to blood in one series were attributable to such abnormalities[5],[6].

The operation of such placenta anomalies is known to be linked to considerable, life-threatening, intra-operative bleeding[7]. Lifesaving can be achieved with the use of an extremely powerful uterotonic such as misoprostol at this vital period. Pathological adhesion of the placenta to the uterine surface may make placental priorities complicated and placenta retained. It is a known cause for significant bloody blood flow and common evidence of hysterectomy of the peripartum [1], [7]. Placenta retained is a third phase of labor problem. The theatrical removal of placenta is usually carried out by individuals with retained placenta. The disease is often linked to obstetric bleeding [1].

Misoprostol's debut has transformed obstetrics. The prostaglandin is a synthetic homologue of E1. The tablet is available in several ways and has a wide range of advantages: room temperature stability, long standing, low cost, and multiple administrative channels [4]. Misoprostol is quickly absorbed after administration [4]. It is common for the prevention and treatment of postpartum hemorrhage $(400-1000 \mu \mathrm{g})[3],[4]$, and for cervical maturation and laboratory induction (25-50 $\mu \mathrm{g} 6 \mathrm{~h}$ ). High dose diarrhea, abdomen discomfort and heat are typical side effects[4]. When taken at higher doses. These adverse consequences are less likely to occur locally (vaginally or rectally).

The majority of misoprostol studies in obstetrical bleeding prophylaxis have concentrated on its postpartum use. When women need a considerable volume of intrapartum blood, they often need to lose. Placenta 
malformations may be essential if the potential benefit of these regularly used uterotons is to reduce maternal morbidity and mortality. Because they are the predisposing factor for intrapartal hemorrhage.

\section{MATERIAL AND METHODS}

This prospective comparative study was conducted at $\mathrm{DHQ}$ Zanana hospital Dera Ismail Khan for one year duration from January 2019 to December 2019and comprised of 100 patients. Patients' detailed demographics were recorded after taking informed written consent. Patients had preterm delivery, with multiple pregnancies, antepartum hemorrhage and those did not give any consent were excluded from this study.

Patients were aged between 18-45 years of age. Patients' detailed demographics age, body mass index and parity were recorded after taking informed written consent. Patients were categorized equally into two groups, I and II. Group I had 50 patients and received single dose 400 micrograms of misoprostol transrectally one hour preoperatively and group II had 50 patients and received 2tablets of placebo preoperatively. Outcomes intraoperative blood loss, blood transfusion, hysterectomy and complications among both groups were assessed. Complete data was analyzed by SPSS 23.0 version. Categorical variables were assessed by frequency and percentage.

\section{RESULTS}

Mean age of the patients was $32.16 \pm 9.44$ with mean BMl $26.07 \pm 10.44 \mathrm{~kg} / \mathrm{m}^{2}$. There were no significantly difference among age and body mass among both groups. 60 Patients had 0 parity, 30 patients had parity 1 and the rest were had parity 2. 55 (55\%) patients were educated and 54 (54\%) were from urban area.(Table 1)

Table 1: Baseline details demographics on enrolled cases

\begin{tabular}{|l|l|l|}
\hline Variables & Group I & Group II \\
\hline Mean age & $32.16 \pm 9.44$ & $32.48 \pm 7.44$ \\
\hline Mean BMI & $26.07 \pm 10.44$ & $26.55 \pm 9.44$ \\
\hline Parity & $30(30 \%)$ & $30(30 \%)$ \\
\hline 0 & $15(15 \%)$ & $15(15 \%)$ \\
\hline 1 & $5(5 \%)$ & $5(5 \%)$ \\
\hline 2 & $27(27 \%)$ & $28(28 \%)$ \\
\hline Education Status & $22(22 \%)$ \\
\hline Educated & $23(23 \%)$ & $27(27 \%)$ \\
\hline Uneducated & $27(27 \%)$ & $23(23 \%)$ \\
\hline Residency & $23(23 \%)$ \\
\hline Urban
\end{tabular}

There was no any significantly difference in uterine size among both groups.

Mean pre-operative hemoglobin in group I was $13.64 \pm 8.55$ and post-operative was $9.88 \pm 8.55$ and in group II mean pre-operative hemoglobin was $13.55 \pm 8.55$ and post-operative was $9.12 \pm 5.55$.(Table 2 )

Table 2: Comparison of hemoglobin among both groups

\begin{tabular}{|l|l|l|}
\hline Variables & Group I & Group II \\
\hline Hemoglobin & $13.64 \pm 8.55$ & $13.55 \pm 8.55$ \\
\hline Pre-operative & $9.88 \pm 8.55$ & $9.12 \pm 5.55$ \\
\hline Post-operative
\end{tabular}

Mean intraoperative blood loss in group I was $388.17 \pm 37.18 \mathrm{ml}$ and in group II was $501.16 \pm 17.64 \mathrm{ml}$. Post-operatively blood transfusion in group I was among $2(4 \%)$ cases and $3(6 \%)$ in group II. Mean hospital stay in group II was greater as compared to group I. (Table 3)

Table 3: Comparison of intraoperative blood loss and postoperative blood transfusion among both groups

\begin{tabular}{|l|l|l|}
\hline Variables & Group I & Group II \\
\hline $\begin{array}{l}\text { Intra-operative blood } \\
\text { loss (ml) }\end{array}$ & $388.17 \pm 37.18$ & $501.16 \pm 17.64$ \\
\hline Blood Transfusion & $2(4 \%)$ & $3(6 \%)$ \\
\hline Yes & $48(96 \%)$ & $47(94 \%)$ \\
\hline No & 50 & 50 \\
\hline Total &
\end{tabular}

Table 4: Nausea, vomiting and shivering were the complications found in this study.

\begin{tabular}{|l|l|l|}
\hline Variables & \multicolumn{1}{l|}{ Group I } & Group II \\
\hline Nausea & $2(4 \%)$ & $1(2 \%)$ \\
\hline Yes & $48(96 \%)$ & $49(98 \%)$ \\
\hline No & $1(2 \%)$ & $2(4 \%)$ \\
\hline Vomiting & $49(98 \%)$ & $48(96 \%)$ \\
\hline Yes & \multicolumn{2}{|l|}{} \\
\hline No & $3(6 \%)$ & $1(2 \%)$ \\
\hline Shivering & $47(94 \%)$ & $48(96 \%)$ \\
\hline Yes
\end{tabular}

\section{DISCUSSION}

Myomectomy is a symptom uterine fibroid therapy that maintains fertility. An uncontrolled interoperational bleeding with life-threatening complications is the biggest operative risk that makes the surgery even more dangerous than the hysterectomy and involves an expert surgeon. The main approach to uterine leiomyome management remains conserve surgery, and laparotomy myomectomy is still the most widely applied method in many centers around the World. Still, bleeding is frequently problematic and can lead to intraoperative hypovolematic shock, postoperative anemia, pelvic diseases and infertility adhesions. Several therapies to minimize myomectomy blood, including ergotone (ergometrine), misoprostol, hormonal tourniquet, and uterine artery dissection, have been been out. Mechanical tourniquet peri-cervical. [8]

The strength of the study is that preoperative misoprostol has been compared to placebo, which is rare in the literature, the randomized design and the objective blood loss measurements. The limitation of the sample size and the study area includes. In this study 100 patients were presented with mean age $32.16 \pm 9.44$. 55 (55\%) patients were educated and 54 (54\%) were from urban area. Our findings were comparable to the previous study.[9] In this study 400 micrograms of misoprostol transrectally one hour preoperatively were given to 50 patients and 2-tablets of placebo were given to other group of 50 patients. We found reduction in hemoglobin from $13.64 \pm 8.55$ to $9.88 \pm 8.55$ in group I and in group II mean pre-operative hemoglobin was $13.55 \pm 8.55$ and post-operative was 9.12 \pm 5.55 .[10]

Misoprostol has been reported to be effective in reducing blood loss in myomectomy following comparison with placebo [11-13] or other agents.[14] In current study mean blood loss in group I was $388.17 \pm 37.18 \mathrm{ml}$ and in 
group II was $501.16 \pm 17.64 \mathrm{ml}$. Several trials employed misoprostol in myomectomy with varying dose regimes. A trial conducted three hours before surgery using $200 \mathrm{mg}$ of vaginally given misoprostol compared to $400 \mathrm{mg}$ of vaginal misoprostol provided an hour before surgery. The influence of the dose and time interval, from misoprostol to the start of surgery on blood loss, is raised in a future research. [12] In our study post-operatively blood transfusion among both group was (4\% and 6\%). These results were comparable to the previous researches in which no or less blood transfusion was presented. [12,15] Celik $\mathrm{H}$ and Spamaz E 2003 also observed that there was hence a significantly lesser demand for blood transfusion in the study group. In the current study, however, the requirement for blood transfusion in the study group was lower but it did not reach statistically significant values and future studies with larger numbers could be required to validate the findings and to give significant values a chance to arise. In the current investigation, the post-op hemoglobin and hematocrit levels were significantly higher in the group study, confirming the effect of misoprostol during myomectomy on blood loss reduction and significantly reduced difference between preand post-operative hemoglobin values. [16]

These results were likewise consistent with the published results (Celik and Spamaz; 2003). [16] Although this study failed to compare with other intraoperative bleeding procedures, there were some advantages of misoprostol over some of them. Compared with preoperative $\mathrm{GnRH}$ use analogs, which is the most popular way of minimizing bleeding in myomectomy, the benefit is in the cost and frequency of administration. The $\mathrm{GnRH}$ analog bleeding reduction is achieved only 2-4 months after lengthy use (Lethabie A et al., 2001)[17]. Analog $\mathrm{GnRH}$ therapy is very costly. Another issue is that treatment for $\mathrm{GnRH}$ agonists could make removal of fibroids harder (Lethaby A et al., 2002). [18]

In our study less hospital stay was observed in misoprostal group as compared to placebo while complication were found greater in misoprostal group. In short, this study demonstrates that blood loss reduction in peri-operative vaginal misoprostol and placebo is comparably beneficial during abdominal myomectomy.

\section{CONCLUSION}

We concluded in this study that the use ofmisoprostol preoperatively during abdominal myomectomy was effective safe and useful in reduction of intraoperative blood loss and post-operatively blood transfusion among patients.

\section{REFERENCE}

1. Mehasseb K, Konje JC. Placental abnormalities. In: Lynch C, Keith LG, Lalonde AB, Karoshi M, editors. A Textbook of Postpartum Haemorrhage. Duncow, UK: Sapiens Publishing; 2006. p. 80-95

2. Knight M, Callaghan WM, Berg C, Alexander S, BouvierColle $\mathrm{MH}$, Ford JB, et al. Trends in postpartum haemorrhage in high resource countries: A review and recommendations from the international postpartum haemorrhage collaborative group. BMC Pregnancy Childbirth 2009;9:55. https://doi. org/10.1186/1471-2393-9-55
3. Thurn L, Wikman A, Westgren M, Lindqvist PG. Massive blood transfusion in relation to delivery: Incidence, trends and risk factors: A population-based cohort study. BJOG. 2019;126(13):1577-86. $\quad$ https://doi.org/10.1097/01. aoa.0000693684.70869.3a PMid:31483935

4. Bellad MB, Goudar S. Misoprostol: Theory and practice. In: Lynch CB, Keita LG, editor. A Textbook of Postpartum Haemorrhage. Duncow, UK: Sapiens Publishing; 2006. p. 114-26.

5. Chickakli LO, Atrash HK, Mackay AP, Musani AS, Berg CJ. Pregnancy-related mortality in the United states due to haemorrhage: 1979-1992. Obstet Gynecol. 1999;94(Pt 1):721 - 5. https://doi.org/10.1097/00006250-19991100000015 PMid: 10546717

6. Chong YS, Su LL, Arulkumaran S. Misoprostol: A quarter century of use, abuse, and creative misuse. ObstetGynecol Survey. 2004;59(2):128-40. https://doi.org/10.1097/01. ogx.0000109168.83489.66 PMid:14752301

7. Elsedeek MS. Impact of preoperative rectal misoprostol on blood loss during the after elective caesarean delivery. Int $\mathrm{J}$ GynaecolObst. 2012;118(2):149-52. https://doi.org/10.1016/j. ijgo.2012.03.038 PMid:22698700

8. Kongnyuy EJ, Wiysonge CS. Interventions to reduce haemorrhage during myomectomy for fibroids. Cochrane Database of Systematic Reviews 2011, Issue 11

9. Afolabi MA, Ezeoke GG, Saidu R, ljaiya MA, Adeniran AS. Comparing perioperative vaginal misoprostol with intraoperative pericervical hemostatic tourniquet in reducing blood loss during abdominal myomectomy: A randomized controlled trial. J Turk GerGynecol Assoc. 2019;20(1):23-30.

10. Kimura T, Kusui, Matsumura Y, Ogita K, Isaka S, Nakajima A. Effectiveness of hormonal tourniquet by vasopressin during myomectomy through vasopressin $\mathrm{V} 1 \mathrm{a}$ receptor ubiquitously expressed in the myometrium. Gynecologic and Obstetric Investigation 2002;54: 125-131

11. Celik H, Sapmaz E. Use of a single preoperative dose of misoprostol is efficacious for patients who undergo abdominal myomectomy. FertilSteril. 2003;79:1207-10

12. Niroomand N, Hajiha S, Tabrizi NM, Ghajarzadeh M. A single dose of misoprostol for reducing haemorrhage during myomectomy: a randomized clinical trial. Arch Gynecol Obstet. 2015;292:155-8

13. Abdel-Hafeez M, Elnaggar A, Ali M, Ismail AM, Yacoub M. Rectal misoprostol for myomectomy: A randomised placebocontrolled study. Austr N Z J ObstetGynaecol. 2015;55:3638

14. Gharabaghi PM, Alizadeh S, Atashkhoye S, Sayyah-Melli M, Jafari- Shobeiri M, Ouladsahebmadarek E, et al. Comparing the Outcomes and Side Effects of Administration of a Single Preoperative Dose of Vaginal Misoprostol With Intraoperative Oxytocin Infusion in Blood Loss During Abdominal Myomectomy. Int J Women's Health Reprod Sci. 2017;5:306-11

15. Ikechebelu JI, Ezeama CO, Obiechina NJ. The use of torniquet to reduce blood loss at myomectomy. Niger $J$ ClinPract. 2010;13:154-8

16. Celik H, Sapmaz E. Use of a single preoperative dose of misoprostol isefficacious for patients who undergo abdominal myomectomy. FertilSteril. 2003;79:1207-1210

17. Lethaby A, Vollenhoven B, Sowter M. Pre-operative GnRH analogue therapy before hysterectomy or myomectomy for uterine fibroids. Cochrane Database Syst Rev 2001; :CD000547

18. Lethaby A, Vollenhoven B, Sowter M. Efficacy of preoperative gonadotrophin hormone releasing analogues for women with uterine fibroids undergoing hysterectomy or myomectomy: a systematic review. BJOG 2002; 109:1097 